\title{
Gender and Technology in the Liberal Arts: Aptitudes, Attitudes, and Skills Acquisition
}

\author{
Terry Butler, Peter Ryan, and Tracy Chao \\ Arts Resource Centre, University of Alberta, Edmonton, Canada
}

\author{
Terry.Butler@UAlberta.ca pryan@ryerson.ca \\ tracy.chao@avantlearning.com \\ Executive Summary
}

Studies in gender have offered many reasons for the differing attitudes and skill levels that male and female undergraduate students possess when it comes to learning technology skills. Male and female students have differing learning styles influenced by such experiential factors as biology, historical inequalities, inconsistent political rights, and problems of sociological constructions. Studies such as Clegg and Trayhurn's (2000) in the United Kingdom (UK), Crews and Butterfield's (2003) in the United States, the European Union's (EU) the Women in Technology North West's surveys (2004), and the World Bank's research (2005) demonstrate that the gender gap is a reality when it comes to technology training, in most institutions and countries, both developed and developing. The gender gap persists despite many efforts to curb the effects of institutional and social inequality. However, the gender gap is different in each context and must be contextualized in each situation; in fact, the gender gap as a term conflates several different arguments and may indeed contribute to misunderstandings of the issue.

In May 2003, the Technology Edge Research Project completed a major study of undergraduate liberal arts students and their attitudes concerning the technology skills that they have gained during university. This report builds upon the findings of the Technology Edge Research Project's preliminary needs assessment; this research was documented in a previous article in the Journal of Information and Technology Education (JITE) entitled, "Providing a Technology Edge for Liberal Arts Students" (Butler, Chao, \& Ryan, 2003).

Elaborating on our findings as they specifically related to gender issues, this paper addresses the following research questions:

1) Is there a gender gap between final year male and female undergraduate students when it comes to information technology (IT) skills?

2) What are the differences in attitudes and self-reported skill levels of final year male and female undergraduate students, in both the arts and non-arts? What is the relationship be-

Material published as part of this journal, either on-line or in print, is copyrighted by the publisher of the Journal of Information Technology Education. Permission to make digital or paper copy of part or all of these works for personal or classroom use is granted without fee provided that the copies are not made or distributed for profit or commercial advantage AND that copies 1) bear this notice in full and 2) give the full citation on the first page. It is permissible to abstract these works so long as credit is given. To copy in all other cases or to republish or to post on a server or to redistribute to lists requires specific permission and payment of a fee. Contact Editor@JITE.org to request redistribution permission. tween these attitudes and measured aptitudes?

3) How can educators address these differences, when they develop and deploy materials designed to improve IT skills?

Keywords: gender, information technology, IT, liberal arts education, computer skills, employability 


\section{Introduction}

There is a widely held view that graduates in liberal arts are at a disadvantage upon first entering the workforce (Krahn \& Bowlby, 2000). They experience lower levels of initial post-graduate employment and lower starting salaries, when compared to their non-arts peers. One reason advanced for this differential is that liberal arts students lack appropriate information technology skills. This view can be seen as a version of the hypothesis which posits a "digital divide": a group of people, whether by race, class, gender, or socio-economic position, who are not taking full advantage of the benefits of the information age.

Our research, conducted under the auspices of Human Resources Development Canada, explored this question through an extensive survey of students graduating from bachelor-level postsecondary programs in three Canadian universities. Comparing the IT skills and attitudes held by liberal arts students with those of their non-arts peers, we found the "digital divide" was neither validated or a useful way to describe the differences between the two populations (Butler, Chao, \& Ryan, 2002; Butler \& Chow, 2004). The students as a whole demonstrated a very high level of skill in core IT areas (basic computer skills, electronic communication, word processing, and the Internet); the arts students had lower skill levels in several other areas, some of which were precisely the areas of interest for employers (whom we surveyed and spoke with through focus groups).

Our Technology Edge project continued, in 2003 and 2004, to develop, pilot, and evaluate learning materials, which were integrated into the curriculum of post-secondary liberal arts courses, and which demonstrated the effectiveness of integrating computing skills training into the academic curriculum. As part of the exploration of various ways that students interact and learn, these training materials attempted to address gender differences that are expressed in different learning styles. (For this research, we take gender to mean the biological, cultural, and formative social differences that exist between the male and female sexes.)

We had discovered significant gender differences, in both skills and attitudes, among arts students in our first student survey. It was important for us to learn how gender inflects students' attitudes toward their own aptitudes, and how it relates to both the computing skills the students already have, and the skills they plan on acquiring in the world of work.

As the Canadian university system supports over 580000 students annually (Statistics Canada, 1999), and both the absolute number and proportion of women is increasing in the university system (Statistics Canada, 2004), we feel these issues are crucial to the widespread development of effective post-secondary IT training strategies.

Tables 1 and 2 summarize full-time and part-time post secondary enrolment, in Canada and each of its provinces, for the years 1995 through 1999 (the latest year for which complete data is available). The provinces of New Brunswick, Alberta, and British Columbia are highlighted; it was in those jurisdictions that we conducted our detailed survey of students' skills and attitudes.

Table 1: Statistics Canada - The Number of Males attending University (Full and Part-time)

\begin{tabular}{|l|r|r|r|r|r|}
\hline & $1994-1995$ & $1995-1996$ & $1996-1997$ & $1997-1998$ & $1998-1999$ \\
\hline & \multicolumn{5}{|c|}{ Male } \\
\hline Full-time enrolment & 178,773 & 182,910 & 185,653 & 185,495 & 186,787 \\
\hline Canada & 3,001 & 2,847 & 2,970 & 3,422 & 3,483 \\
\hline Newfoundland and Labrador & 397 & 510 & 678 & 823 & 1,004 \\
\hline Prince Edward Island & &
\end{tabular}




\begin{tabular}{|c|c|c|c|c|c|}
\hline Nova Scotia & 1,352 & 3,654 & 3,607 & 3,843 & 3,672 \\
\hline New Brunswick & 1,894 & 1,651 & 2,561 & 2,856 & 2,895 \\
\hline Quebec & 78,138 & 77,649 & 74,503 & 73,231 & 72,966 \\
\hline Ontario & 62,304 & 65,747 & 69,281 & 68,684 & 68,914 \\
\hline Manitoba & 1,869 & 1,740 & 1,734 & 1,820 & 1,984 \\
\hline Saskatchewan & 1,475 & 1,280 & 1,151 & 1,221 & 1,054 \\
\hline Alberta & 12,681 & 12,673 & 13,137 & 13,008 & 13,711 \\
\hline British Columbia & 15,253 & 14,958 & 15,882 & 16,429 & 16,937 \\
\hline Yukon & 132 & 62 & 93 & 123 & 105 \\
\hline Northwest Territories & 277 & 139 & 56 & 35 & 62 \\
\hline \multicolumn{6}{|l|}{ Part-time enrolment } \\
\hline Canada & 35,550 & 34,341 & 34,893 & 39,092 & 37,635 \\
\hline Newfoundland and Labrador & 137 & 86 & 69 & 109 & 243 \\
\hline Prince Edward Island & 135 & 116 & 83 & 58 & 58 \\
\hline Nova Scotia & 22 & 41 & 38 & 44 & 96 \\
\hline New Brunswick & 13 & 48 & 81 & 63 & 74 \\
\hline Quebec & 5,205 & 5,170 & 5,178 & 5,157 & 4,355 \\
\hline Ontario & 5,694 & 5,378 & 5,308 & 4,868 & 5,045 \\
\hline Manitoba & 519 & 585 & 937 & 911 & 1,007 \\
\hline Saskatchewan & 106 & 91 & 42 & 40 & 36 \\
\hline Alberta & 6,324 & 5,337 & 5,605 & 6,170 & 6,713 \\
\hline British Columbia & 16,756 & 17,317 & 17,321 & 21,424 & 19,697 \\
\hline Yukon & 144 & 110 & 116 & 152 & 150 \\
\hline Northwest Territories & 495 & 62 & 115 & 96 & 161 \\
\hline
\end{tabular}

Table 2: Statistics Canada - The Number of Females attending University (Full and Part-time)

\begin{tabular}{|l|r|r|r|r|r|r|}
\hline & $1994-1995$ & $1995-1996$ & $1996-1997$ & $1997-1998$ & $1998-1999$ \\
\hline & \multicolumn{5}{|c|}{ Female } \\
\hline Full-time enrolment & & \\
\hline Canada & $\mathbf{2 0 1 , 1 8 8}$ & $\mathbf{2 0 8 , 3 7 2}$ & $\mathbf{2 1 1 , 6 5 5}$ & $\mathbf{2 1 3 , 1 4 8}$ & $\mathbf{2 1 6 , 7 2 9}$ \\
\hline Newfoundland and Labrador & 2,970 & 2,885 & 2,734 & 2,552 & 2,490 \\
\hline Prince Edward Island & 422 & 486 & 597 & 797 & 895 \\
\hline Nova Scotia & 1,413 & 3,172 & 3,349 & 3,464 & 3,367 \\
\hline New Brunswick & $\mathbf{1 , 6 6 6}$ & $\mathbf{2 , 1 0 0}$ & $\mathbf{2 , 2 4 7}$ & $\mathbf{2 , 2 9 6}$ & $\mathbf{2 , 3 2 6}$ \\
\hline Quebec & 93,859 & 93,912 & 92,355 & 90,319 & 91,503 \\
\hline Ontario & 64,129 & 68,756 & 71,924 & 73,669 & 73,427 \\
\hline
\end{tabular}




\begin{tabular}{|l|r|r|r|r|r|}
\hline Manitoba & 2,049 & 1,872 & 1,864 & 1,982 & 2,197 \\
\hline Saskatchewan & 2,001 & 1,883 & 1,636 & 1,974 & 1,686 \\
\hline Alberta & $\mathbf{1 4 , 6 8 0}$ & $\mathbf{1 5 , 2 5 5}$ & $\mathbf{1 6 , 2 2 9}$ & $\mathbf{1 6 , 5 8 7}$ & $\mathbf{1 8 , 2 8 8}$ \\
\hline British Columbia & $\mathbf{1 7 , 5 4 7}$ & $\mathbf{1 7 , 5 1 8}$ & $\mathbf{1 8 , 4 3 1}$ & $\mathbf{1 9 , 1 7 0}$ & $\mathbf{2 0 , 1 9 0}$ \\
\hline Yukon & 145 & 196 & 179 & 195 & 153 \\
\hline Northwest Territories & 307 & 337 & 110 & 143 & 207 \\
\hline Part-time enrolment & & & & & \\
\hline Canada & $\mathbf{5 5 , 2 6 0}$ & $\mathbf{5 3 , 3 4 8}$ & $\mathbf{5 2 , 1 8 8}$ & $\mathbf{5 2 , 4 8 5}$ & $\mathbf{5 3 , 8 0 4}$ \\
\hline Newfoundland and Labrador & 69 & 42 & 38 & 68 & 228 \\
\hline Prince Edward Island & 242 & 203 & 61 & 17 & 17 \\
\hline Nova Scotia & 216 & 216 & 249 & 351 & 230 \\
\hline New Brunswick & $\mathbf{2 9}$ & $\mathbf{5 2}$ & $\mathbf{8 9}$ & $\mathbf{5 8}$ & $\mathbf{6 9}$ \\
\hline Quebec & 7,405 & 6,769 & 5,831 & 5,117 & 4,604 \\
\hline Ontario & 6,658 & 6,155 & 5,525 & 5,231 & 5,198 \\
\hline Manitoba & 853 & 772 & 1,208 & 1,535 & 1,506 \\
\hline Saskatchewan & 355 & 152 & 117 & 117 & 53 \\
\hline Alberta & $\mathbf{1 0 , 4 2 6}$ & $\mathbf{9 , 7 5 4}$ & $\mathbf{9 , 7 9 7}$ & $\mathbf{1 0 , 3 7 3}$ & $\mathbf{1 1 , 1 2 5}$ \\
\hline British Columbia & $\mathbf{2 8 , 2 5 4}$ & $\mathbf{2 8 , 7 3 9}$ & $\mathbf{2 8 , 6 1 2}$ & $\mathbf{2 8 , 9 0 0}$ & $\mathbf{2 9 , 9 5 7}$ \\
\hline Yukon & 217 & 198 & 266 & 343 & 304 \\
\hline Northwest Territories & 536 & 296 & 395 & 375 & 513 \\
\hline Note: Includes related institutions & & & & & \\
cialized colleges. & as hospital schools and agricultural, arts, and other spe- & & \\
\hline
\end{tabular}

Gender issues affect not only the students in post-secondary, but also the instructors. Not only are more women attending university, but there are also more female faculty members. Sussman and Yssaad note several factors that are contributing to an increasing proportion of female academics in the university system:

Women have increased their presence among full-time university faculty during a period of shrinking public funding, rising enrolments and increasing tuition costs. The trend has been fuelled by the rising educational attainment of women generally, as well as a growing academic work force reaching retirement age that consists mainly of men (Sussman \& Yssaad, 2005).

In developing our research agenda, attitudes and self-reported skill levels were explicitly correlated with gender, in order to help understand how the process of technology skills acquisition differs between the sexes. We wished to see if our results would support an across-the-board differentiation in skills and attitudes between males and females: a broad set of differences could be reasonably categorized as a "gender gap". If, on the other hand, the distinctions we found (if at all statistically significant) were as various and nuanced as those we found between arts and non-arts students, we would hesitate to invoke a heavy-handed discriminator such as the "gender gap". 


\section{Brief Overview of the Project}

The Technology Edge Research Project is a collaborative effort of three Canadian universities: the University of Alberta, the University of British Columbia, and the University of New Brunswick. For the survey conducted in 2003, the liberal arts disciplines are defined broadly to include the fields of fine arts, the humanities, and the social science disciplines, and in the remainder of this paper, we use the term "arts" to include all of these disciplines. For example, at the University of Alberta, the specific disciplines included under arts are shown in Table 3.

Table 3: The Breakdown of Arts Disciplines at the University of Alberta

\begin{tabular}{|l|l|l|}
\hline \multicolumn{1}{|c|}{ Fine Arts } & \multicolumn{1}{|c|}{ Humanities } & \multicolumn{1}{c|}{ Social Sciences } \\
\hline Art and Design & Chinese Literature/Language & Anthropology \\
Art History & Classics & Canadian Studies \\
Drama & Comparative Literature & Economics \\
Music & Creative Writing & History \\
& East Asian Studies & Linguistics \\
& English & Political Science \\
& French Language/Literature & Psychology \\
& Film and Media Studies & Sociology \\
& Languages & Women's Studies \\
& Philosophy & \\
& Religious Studies & \\
\hline
\end{tabular}

Similarly, the Arts Faculties of the University of British Columbia and the University of New Brunswick are arranged under similar structures (University of British Columbia, 2002; University of New Brunswick 2002).

For a more in-depth description of this project's methodology and the early work on the first two phases, please see our report "Providing a Technology Edge for Liberal Arts Students" (Butler, Chao, \& Ryan, 2003) in the Journal of Information and Technology Education (JITE).

The main focus of the present paper are the findings concerning gender differences as discovered in the Technology Edge's 2003 student survey; these results complement those reported in the 2003 JITE paper. The 2003 paper reports the overall results of the student survey, which measured students' attitudes and self-reported IT skill levels and made comparisons between liberal arts and non-arts disciplines at the three Canadian institutions mentioned above.

\section{Literature Review of the Sexes and Technology Skills}

Because arts has a higher portion of female students than male students in Canada (67\% vs. 33\%), gender becomes an important variable when shaping the learning needs of students. Research conducted in the 1990s indicated that females were usually less experienced than males with regards to their use of computers both at home and in higher education (Dain, 1991; Durndell, Glissov, \& Siann, 1995; Shashaani, 1995). In 2001, the fact that "only 15 percent to 20 percent of computer science majors" were female at major universities in the United States was a source of embarrassment ("Computer Gender Gap," 2001). A snapshot taken during the recent turn of the century provided this description of the situation:

Carnegie Mellon University's associate dean for undergraduate education Peter Lee warns that this gender gap can have a detrimental effect on computing as well as women. Studies by researcher Faye Miller and Carnegie Mellon professors Jane Margolis and Allan Fisher found that women are far less obsessive over computers than men and are unwilling to sacrifice relationships and quality time in the name of com- 
puter science. Furthermore, there are greater numbers of boys entering college who have experience with computers and electronics than girls, according to John Guttag of MIT. (“Computer Gender Gap,” 2001)

Margolis and Fisher's book Unlocking the Clubhouse (2002) documents some of the successes that Carnegie Mellon had in decreasing the gender gap by tweaking its computer science program. For example, there was a surprising increase from 1995 to 2000 in the percentage of female computer science majors, which changed from 7 percent to 40 percent. Also, their closing surveys signify that male and female students' dropout rates were equivalent; however, in 1995 women were twice as likely to leave the program.

The work we are doing here builds upon a well-established area of research; one in which substantial and carefully documented literature reviews have been completed. Studies such as Crews and Butterfield's (2003) in the United States, Clegg and Trayhurn's (2000) in the United Kingdom (UK), the European Union's (EU) Women in Technology North West's surveys (2004), and the World Bank's research (2005) document a gender imbalance on a global scale. For example, Crews and Butterfield find that in the United States the gender gap in computing has remained a persistent issue, while the discrepancy in other fields is shrinking. They write:

The problem of gender equity in IT is decades old. The Department of Education in the United States shows that from 1983-84 through 1997-98 there was a 28\% decrease in the percentage of women earning bachelor's degrees in computing. The Department of Education data is particularly revealing as it also shows a steady increase of women choosing to study in other science fields during that same time. From 1984 to 1998 there was an $18 \%$ increase in the percentage of women earning bachelor's degrees in Biology/Life Sciences, a 31\% increase in women earning Engineering degrees, a $6 \%$ increase in women earning Math degrees, and an $11 \%$ increase in women earning Physics degrees. (Crews \& Butterfield, 2003, p. 69)

In their study, Crews and Butterfield assert that interactive teaching styles which better match female learning approaches should be applied immediately to IT training. Their study finds, similarly to Margolis and Fisher's, that increases in attracting and retaining women in the field of IT do occur when attention is paid to creating educational outcomes based on those learning approaches. As well, they suggest broad cultural changes such as: "removing gender bias in computer software, increasing female access to, and experience with computers, increasing the number of female role models in the profession, and even developing more "girl-friendly" computer games" (p. 70).

In Britain, Clegg and Trayhurn (2000) take a related approach in questioning the gender gap. They argue, instead of asking what is wrong with women's skills, the question should be what is wrong with how computing is being taught. They find that women have increased success in IT training by teaching computing as a concrete set of complex practices and skills, and not an abstract, elite masculine craft. They also note, while men have success in technical skills and computer gaming, it has long been established that women have administrative skills in the IT arena. In these most recent studies, identifying the nuances that challenge the notion of a homogenous gender gap is becoming the best way to dispel the mythology surrounding computing training. As well, using the success stories of training women in other fields has demonstrated that this gap can be shrunk through integrated learning strategies.

The gender gap, as it plays out in the arena of technology skills, is now a common theme of introductory New Media textbooks. Studies point out that the gender gap in this dimension often leads to income differentiation (Lister, Dovey, Giddings, Grant, \& Kelly, 2003). The fact of differentiation (in skills, in incomes, in attitudes) is more easily documented than resolved. It is one of the goals of our Technology Edge project to identify the nature of these differences, with re- 
spect to information technology as it applies to post-secondary arts education; and by piloting a variety of learning solutions, to find means of addressing the different modes of learning present in the student population. This approach meets the call for innovative research studies and integrated IT training, with strategies based on differences in gender learning styles, which has recently been made (Margolis \& Fisher, 2002).

One specific dimension of the gender gap is the lower initial rates of employment for arts, versus non-arts, graduates. (This differentiation plays out as a gender difference because arts have a higher female rate of participation, non-arts a higher male rate.) This difference was explored by Robert Allen (1999). Allen first examined the unemployment rates across arts and professional disciplines, as shown in Table 4. The data showed that those graduates of bachelor programs in fine arts, humanities, and, at least for men, in the Social Sciences, tend to have a higher initial unemployment rate than other non-arts areas of study (Fine Arts - Men: $6.5 \%$, Women 5.9\%; Humanities - Men $6.7 \%$, Women $7.0 \%$ ).

Table 4: Unemployment Rates by field, bachelor degrees, 25-29 year olds, 1996 (Source: Allen, 1999, p. 20, Table 2)

\begin{tabular}{|l|c|c|}
\hline & Women & Men \\
\hline Education & $2.9 \%$ & $3.5 \%$ \\
\hline Fine arts & 5.9 & 6.5 \\
\hline Humanities & 7.0 & 6.7 \\
\hline Social Sciences & 3.4 & 5.5 \\
\hline Commerce & 4.3 & 4.3 \\
\hline Agric/Bio & 7.2 & 4.6 \\
\hline Engineering & 8.8 & 4.3 \\
\hline Nursing & 3.1 & 0.0 \\
\hline Other Health & 0.6 & 5.7 \\
\hline Math/Physics & 7.8 & 3.8 \\
\hline \multicolumn{2}{|c|}{ Note: excludes people in school in the previous year. “Other” is excluded. } \\
\hline
\end{tabular}

But Allen's analysis continued, making an important distinction: he argues that liberal arts graduates in general have the intellectual and interpersonal abilities to cope with organizational changes and to solve problems in the rapidly changing environment brought on by the information technology revolution. The lower levels of initial employment, and lower starting salaries, experienced by arts graduates, after a few years become equal or even higher than their non-arts peers (Allen, 1999).

Many authors have written about the value of a liberal arts education in the information age. IT skills for arts students have often been associated with the concept of information literacy. From this perspective, basic computing competence is viewed as an essential background or underpinning to an arts education (Agee \& Holisky, 2000; Breivik \& Jones, 1993; Conroy, 2001; Herman, 2000; Lyman, 1996, 2001; Shapiro \& Hughes, 1996).

Our research has shown a very high level of basic computer literacy, among both arts and nonarts bachelor level graduates. "Information literacy" (which suggests a baseline level of skill, which we see is now amply met) can give way, as an organizing principle for the discussion, to a more nuanced view of the strengths and weakness of arts' students computing skills, including a gendered view, and relating the computing skills directly to the overarching skills for which arts 
students are most valued in the workplace: communications skills, the ability to work in teams, and critical thinking.

The discussion around arts students' employability needs to move beyond a "whether or not" arts students are employable to focus on "what" makes them more employable, and in what ways are they more successful once employed. In studying that transition, the gender differential must be addressed, in order to ensure that skills training and integration are effective for both male and female students, and to understand what aspects of gender attitudes are influencing the differentials, which appear in the statistics as both lower rates of employment and lower salary levels for females.

Elaborating on these issues of gender inequality, this paper addresses the following research questions:

1) Is there a gender gap between final year male and female undergraduate students when it comes to information technology (IT) skills?

2) What are the differences in attitudes and self-reported skill levels of final year male and female undergraduate students, in both the arts and non-arts? What is the relationship between these attitudes and measured aptitudes?

3) How can educators address these differences, when they develop and deploy materials designed to improve IT skills?

\section{Methodology}

After consulting several existing surveys on similar topics, we devised a detailed hour-long survey directed at fourth year undergraduate students to measure students' attitudes toward and aptitudes with IT. Egnatoff's "Computers and Lifelong Learning" (2002) and McEuan's "How fluent with information technology are our students?" (2001) are two of the previous surveys from which we benefit. Technical assistance was provided by the University of Alberta's Population Research Laboratory.

We knew that we needed to address the challenge of getting accurate information about students' skills through the vehicle of a telephone/in-person survey. Our experience with providing computer training for post-secondary students made us aware that students often do not have an accurate view of their own skill levels relative to their peers, nor a good baseline of information about what would constitute "beginner" or "advanced" levels of skill. We therefore developed a detailed series of drill-down questions in each of the computer skill categories we inquired about, which we felt would allow us to characterize students' skills independent of their own self-assessment. For example, in the area of email, we asked specific questions about address books, mailing lists, and attachments: although the students' level of skill was not being directly measured, we felt that the answers to these questions would allow us to distinguish beginners from advanced users, at least in broad outlines.

After a test run of the survey, which led to some editorial changes, the revised and refined Technology Edge survey was conducted between March and April 2002.

Students were randomly selected to participate in the study. At two of the universities, students were interviewed by telephone: the other university surveyed students face-to-face, using the same survey (with minor editorial modifications for the different format of the interview). The numbers of students surveyed are shown in Table 5. 
Table 5: Number of Students Participating, by Institution and Arts/Non-Arts

\begin{tabular}{|l|c|c|c|}
\hline Institution & $\begin{array}{c}\text { Arts } \\
\text { Students }\end{array}$ & $\begin{array}{c}\text { Non-Arts } \\
\text { Students }\end{array}$ & Total \\
\hline University of Alberta & 408 & 196 & 604 \\
\hline University of British Columbia & 125 & 27 & 152 \\
\hline University of New Brunswick & 99 & 51 & 150 \\
\hline Totals & 632 & 274 & 906 \\
\hline
\end{tabular}

The respondents broken down by gender are shown in Table 6.

Table 6: Number of Students Participating, by Institution, Gender, and Arts/Non-Arts

\begin{tabular}{|l|c|c|c|c|c|}
\hline Institution & \multicolumn{2}{|c|}{$\begin{array}{c}\text { Arts } \\
\text { Students }\end{array}$} & \multicolumn{2}{c|}{$\begin{array}{c}\text { Non-Arts } \\
\text { Students }\end{array}$} & Total \\
\hline & Male & Female & Male & Female & \\
\hline University of Alberta & 134 & 274 & 89 & 107 & 604 \\
\hline University of British Columbia & 45 & 80 & 17 & 10 & 152 \\
\hline University of New Brunswick & 31 & 68 & 26 & 25 & 150 \\
\hline Total by Gender & 210 & 422 & 132 & 142 & \multirow{2}{*}{906} \\
\hline Total & \multicolumn{3}{|c|}{632} & \multicolumn{2}{|c|}{274} \\
\hline
\end{tabular}

Arts students were sampled at approximately a 1:3 ratio, while non-arts students were sampled at about a 1:20 ratio. This stratified sampling allowed the researchers to examine the differences in various arts disciplines in more detail, yet have a sufficient sample size from the non-arts population to form a comparison base. The arts population includes traditional humanities and liberal arts disciplines, as well as those categorized as social sciences and the performing arts. Non-arts students are defined for the purposes of the survey as those in business, education, engineering, physical education, and science (professional and technical disciplines were excluded). A screening process was implemented at the beginning of each interview to ensure that only those students who were to graduate in 2002 from a bachelor-level program completed the survey. Questions in the survey were designed to assess the students' IT skill competencies (through an inventory of self-reported skill attainment and drill-down detailed questions about each skill area), attitudes toward IT, and preferred ways of acquiring those skills. IT skills were explored under twelve categories:

(1) basic computer skills

(2) electronic communication

(3) word processing

(4) bibliographic programs

(5) databases

(6) spreadsheets

(7) statistical programs

(8) presentations

(9) graphics programs

(10) Internet

(11) web creation

(12) the understanding of how computers work 
As well, attitudes were recorded in five separate categories:

(1) Enjoy working with computers

(2) Feel comfortable talking about computers with others

(3) Learn new computer skills easily

(4) Feel confident to master IT skills

(5) IT skills are useful in advancing one's career.

For a more in-depth description of this project's methodology, please see our preliminary report in the Journal of Information and Technology Education (JITE) entitled, "Providing a Technology Edge for Liberal Arts Students" (Butler, Chao, \& Ryan, 2003).

\section{Results}

\section{Skills Inventory}

We were not surprised to learn that both female and male arts students have high competence in four skill sets: (1) basic computer skills, (2) electronic communication, (3) word processing, and (10) Internet. This high level of competence is shared with non-arts students (again, both male and female). We termed these four areas the generic computing skill set; it is clear that postsecondary academic work now exercises these skills routinely. This result, when coupled with the very high rates of computer use and ownership that students now demonstrate (EDUCAUSE Core Data Service Summary, 2003) makes it abundantly clear that this level of computer literacy, only a few years ago a subject of great concern in the literature, is now the norm for almost every graduating student at these institutions. We would expect similar results at other North American institutions with comparable academic and socio-economic profiles.

Significant difference was found in bibliographic, graphics programs, web site creation and conceptual understanding of IT, where males reported higher skills than females (Please see Table 7). [An independent group t-test was used to compare the two groups.]

Table 7: Summary of Students' IT Skill by Faculty

\begin{tabular}{|c|c|c|c|c|c|c|}
\hline \multirow{3}{*}{$\begin{array}{l}\text { Self-Reported } \\
\text { Skill Level }\end{array}$} & \multicolumn{3}{|c|}{$\mathrm{n}=632$} & \multicolumn{3}{|c|}{$\mathrm{n}=274$} \\
\hline & \multicolumn{3}{|c|}{$\begin{array}{c}\text { Arts } \\
\text { (mean) }\end{array}$} & \multicolumn{3}{|c|}{$\begin{array}{c}\text { Non-Arts } \\
\text { (mean) }\end{array}$} \\
\hline & Male & Female & Sig. & Male & Female & Sig. \\
\hline Basic computer skills & .99 & .99 & & 1.00 & .99 & \\
\hline E-communication & 1.00 & 1.00 & & .99 & 1.00 & \\
\hline Word processing & .99 & 1.00 & & 1.00 & .99 & \\
\hline Bibliographic program & .30 & .20 & $* *$ & .29 & .21 & $*$ \\
\hline Spreadsheet program & .84 & .84 & & .99 & .96 & \\
\hline Database program & .57 & .56 & & .77 & .70 & \\
\hline Statistical program & .56 & .55 & & .79 & .51 & $*$ \\
\hline Presentation program & .71 & .64 & & .93 & .83 & $*$ \\
\hline $\begin{array}{l}\text { Graphics/ illustration } \\
\text { programs }\end{array}$ & .65 & .48 & $* * *$ & .71 & .62 & \\
\hline Internet & 1.00 & 1.00 & & 1.00 & 1.00 & \\
\hline Website creation & .44 & .28 & $* * *$ & .71 & .52 & $*$ \\
\hline
\end{tabular}




\begin{tabular}{|l|c|c|c|c|c|c|}
\hline $\begin{array}{l}\text { Understanding how } \\
\text { computers work }\end{array}$ & .87 & .75 & $* * *$ & .94 & .83 & $*$ \\
\hline
\end{tabular}

$(*=\mathrm{p}<0.05 / * *=\mathrm{p}<0.01 / * * *=\mathrm{p}<0.001 ;$ t-test, statistical significance within arts/non-arts gender comparison grouping)

\section{Attitudes}

Students' views on the four generic skills are consistent with their competencies: they highly value these skills. Interestingly, significant difference was found in basic computer tasks, spreadsheet and database skills, where arts female students scored higher than male students. This is an intriguing point since male and female students demonstrate equal competencies in those skill categories (Table 8). However, their views on the importance of these skills diverge.

Table 8: Self-reported Importance of IT Skills for Career (Arts/Non-Arts)

\begin{tabular}{|c|c|c|c|c|c|c|}
\hline \multirow{3}{*}{ Self-reported Importance } & \multicolumn{3}{|c|}{$\mathrm{n}=632$} & \multicolumn{3}{|c|}{$\mathrm{n}=274$} \\
\hline & \multicolumn{3}{|c|}{$\begin{array}{c}\text { Arts } \\
(\text { mean) }\end{array}$} & \multicolumn{3}{|c|}{$\begin{array}{c}\text { Non-Arts } \\
\text { (mean) }\end{array}$} \\
\hline & $\begin{array}{c}\text { Male } \\
\mathrm{n}=208\end{array}$ & $\begin{array}{l}\text { Female } \\
\mathrm{n}=424\end{array}$ & Sig. & $\begin{array}{c}\text { Male } \\
\mathrm{n}=129\end{array}$ & $\begin{array}{l}\text { Female } \\
\mathrm{n}=135\end{array}$ & Sig \\
\hline Basic computer skills & .92 & .97 & $* *$ & .96 & .98 & \\
\hline E-communication & .93 & .94 & & .96 & .97 & \\
\hline Word processing & .96 & .98 & & .96 & .99 & \\
\hline Bibliographic program & .44 & .50 & & .39 & .41 & \\
\hline Spreadsheet program & .62 & .73 & $* *$ & .87 & .87 & \\
\hline Database program & .50 & .60 & $* *$ & .76 & .65 & $*$ \\
\hline Statistical program & .51 & .56 & & .68 & .63 & \\
\hline Presentation program & .82 & .84 & & .90 & .90 & \\
\hline $\begin{array}{l}\text { Graphics/ illustration pro- } \\
\text { grams }\end{array}$ & .53 & .58 & & .55 & .73 & $*$ \\
\hline Internet & .96 & .96 & & .96 & .93 & \\
\hline Website creation & .40 & .36 & $*$ & .30 & .28 & \\
\hline $\begin{array}{l}\text { Understanding how com- } \\
\text { puters work }\end{array}$ & .64 & .57 & & .70 & .64 & \\
\hline
\end{tabular}

$(*=\mathrm{p}<0.05 / * *=\mathrm{p}<0.01 / * * *=\mathrm{p}<0.001 ;$ t-test, statistical significance within Arts/Non-Arts gender comparison grouping)

Generally, we can see female arts students generally value IT skills more highly than their male counterparts. This is true in spite of the fact they report lower levels of skills than males in several of these skill areas (and do not have a statistically significant higher level of skill in any category). Therefore, one might view these attitudes toward IT as reinforcing a gender gap, as women generally value more highly skills which they (at least at present) do not possess.

We found no statistically significant gender difference in arts students' aptitude and their comfort with IT, except when we asked "do you feel comfortable talking about computers?" Female students feel less comfortable talking about computers than male students do (Table 9). 
Table 9: Arts students' aptitude towards IT by sex

\begin{tabular}{|l|c|c|c|}
\hline \multicolumn{1}{|c|}{ Aptitude } & \multicolumn{2}{|c|}{$\mathbf{N = 6 3 2}$} & \\
\hline & $\begin{array}{c}\text { Arts } \\
\text { male } \\
\text { (mean) }\end{array}$ & $\begin{array}{c}\text { Arts female } \\
\text { (mean) }\end{array}$ & Sig. \\
\hline Enjoy working with computers & .90 & .87 & \\
\hline Feel comfortable talking about computers with others & $\mathbf{. 8 8}$ &. $\mathbf{7 4}$ & $* * *$ \\
\hline Learn new computer skills easily & .89 & .89 & \\
\hline Feel confident to master IT skills & .98 & .95 & \\
\hline IT skills are useful in advancing one's career & .92 & .95 & \\
\hline
\end{tabular}

$(*=\mathrm{p}<0.05 / * *=\mathrm{p}<0.01 / * * *=\mathrm{p}<0.001 ;$ t-test, significant at .05 level $)$

\section{Discussion}

To what extent is the imbalance between arts and non-arts students, with respect to computing skills, an artefact of the gender gap: is it due to higher rates of participation by females in arts, and males in non-arts disciplines? Our study shows female non-arts students have lower levels of reported skills than their non-arts male peers, but not as low as female arts students. Gender alone does not provide a convincing explanatory factor.

The distinction between generic IT skills, and more specific IT skills allows us to better explain these phenomena. The uniform high level of skill in the four areas termed the generic IT skill set shows that students, given an opportunity and requirement to use IT skills to accomplish their academic work, will master those skills (at least, by the end of a four year bachelor level degree). The areas of deficiency for arts students are specific content areas (database, spreadsheet, graphics, presentation, web development) that may not be called upon during their academic program. We know that web site creation, spreadsheet, database, and presentation skills are explicitly targeted in the curriculum of some of the non-arts disciplines. At the universities surveyed here, there is no comparable IT curriculum component across the entire arts spectrum.

In our survey, the arts population consisted of $33 \%$ of male and $67 \%$ of female, proportional to the actual demographics. Our survey results are generally in line with previous research findings that demonstrate females are usually less experienced than males with regards to their use of computers both at home and in higher education (Dain, 1991; Durndell, Glissov \& Siann, 1995; Shashaani, 1995). However, these findings also support the nuanced approach to IT training that Clegg and Trayhurn (2000) and Crews and Butterfield (2003) argue is needed to shatter the notion of a homogenous gender gap. The changes that Carnegie Mellon and other schools have made on smaller levels are examples required to eventually make an across the board revamping of IT training in order to improve upon the IT skills that women already possess.

Important to note, in our study attitudes did not track proportionately with skills, and we found several areas where females perceived IT skills to be of greater value, yet they did not report that they possessed these skills. This combination would certainly lead to a lower degree of confidence in their performance in these areas, as they make the transition to the world of work. Such findings are not incommensurate with other studies such as Clegg and Trayhurn (2000) and Crews and Butterfield (2003) which noted shifts in attitudes, from negative to positive, once IT training was modified towards distinct, concrete practices with female learning outcomes taken into account.

Based on our preliminary survey, we have identified cracks in the argument that a homogenous gender gap in IT training exists; however, in this case, between the arts and non-arts communi- 
ties, and not just in computing science generally. We believe that once targeted interactive teaching methods for IT training are implemented, the gender gap will be decreased, as Clegg and Trayhurn (2000) and Crews and Butterfield have argued. Such an outcome will be the focus of our continuing study on IT training in the arts.

\section{Next Steps}

In order to identify the factors that contribute to the results reported here, we tailored the second phase of our project in an attempt to better understand the differences between male and female students as they acquire IT skills. We have taken the following steps:

1) Developed pilot learning materials that will teach computing skills in a fashion integral to the content of the academic courses, and piloted these materials in three liberal arts courses in the fall of 2004.

2) Are developing a five-year, longitudinal study of undergraduate students over their entire degree that tests their IT skills and documents the acquisition of these skills through the duration of the bachelor program. This study is scheduled to begin in September 2006 and further research results will be reported as they appear.

We believe that only through continued efforts of innovative teaching strategies, targeted studentfocused awareness programs, and better support for faculty education on this topic, will any progress be made toward understanding and eliminating gender effects in the acquisition and appreciation of computing skills for liberal arts students.

\section{Acknowledgements}

The Technology Edge Project Team acknowledges the following contributions from our partner institutions: Anne Higgins and Penny Short, University of New Brunswick; Margaret Wicken, Orion Marketing Research; and Ulrich Rauch and Emiela Kaufman, University of British Columbia. Special thanks to Harvey Krahn, University of Alberta for his assistance on the data analysis, and to Tracy Chao, Royal Roads College, for her work on the first phase of this project.

\section{Summary of the Technology Edge Project}

The Technology Edge Research Project has developed, since its inception in 2001, several linked activities:

Phase I: Needs Assessment (complete: 2002)

- discover the differences in information technology (IT) competencies between 4th year liberal arts and non-arts students -- vehicle: telephone survey, face to face survey

- solicit detailed descriptions of the expectations of employers for arts students IT competencies -- vehicle: focus groups, employers online survey

Phase II: Design and Development (complete: 2002-2003)

- develop learning materials and learning strategies which address students' IT skill needs - multimedia and website materials development

- integrate these materials into liberal arts courses, including the assessment of students' work against IT skill criteria

- evaluate the effectiveness of the materials and methods, for both instructors and students -- paper-based surveys, interviews 
Phase III: Create an Electronic Portfolio Mechanism (complete: 2003-2004)

- develop an e-portfolio system for students to store, evaluate, and present their work in a stable and persistent system -- software development

Phase IV: Longitudinal Skills Testing (proposed: 2005-2010)

- test incoming post-secondary students' IT skills and attitudes, and follow these students through four years of post-secondary study, mapping their skills improvement and finding out how and when they acquire new IT skills -- longitudinal survey, hands-on testing

\section{References}

Agee, A. S., \& Holisky, D. A. (2000). Technology across the curriculum at George Mason University. EDUCAUSE Quarterly, 4, 6-12.

Allen, R. C. (1999). Education and technological revolutions: The role of the social sciences and the humanities in the knowledge based economy. Vancouver, B.C. Available online at http://www.sfu.ca/ wwwdoa/allen99.pdf

Breivik, P. S., \& Jones, D. L. (1993). Information literacy: Liberal education or the information age. Liberal Education, 79(1), 6.

Butler, T., \& Chao, T. (2004). Technology Edge: Pilot Implementation and Evaluation. Final project report to Human Resources Development Canada. Executive summary available online at http://www.arts.ualberta.ca/TechEdge/peexecutive.htm

Butler, T., Chao, T. \& Ryan. P. (2002). Technology Edge: Needs Assessment. Final project report to Human Resources Development Canada. Executive summary available online at http://www.arts.ualberta.ca/TechEdge/naexecutive.htm

Butler, T., Chao, T. \& Ryan. P. (2003). Providing a Technology Edge for Liberal Arts Students: Needs Assessment Report. Journal of Information Technology Education (JITE), 2, 331-348. Available online at http://www.jite.org/documents/Vol2/v2p331-348-95.pdf

Conroy, F. (2001). In a technocratic age, study of the liberal arts is even more important. Christian Science Monitor, 93, 163.

Clegg, S., \& Trayhurn. D. (2000). Gender and computing: Not the same old problem. British Educational Research Journal, 26(1), 75.

The computer gender gap. (2001, July 31). The Boston Globe. Summary available at http://istserv.educause.edu/cgi-bin/wa.exe?A2=ind0108\&L=edupage $\& \mathrm{~T}=0 \& \mathrm{~F}=\& \mathrm{~S}=\& \mathrm{P}=73$

Crews, T., \& Butterfield. J. (2003). Improving the learning environment in beginning programming classes: An experiment in gender equity. Journal of Information Systems Education, 14(1), 69.

Dain, J. (1991). Women and computing: Some responses to falling numbers in higher education. Women's Studies International Forum, 14, 217-225.

Durndell, A., Glissov, P., \& Siann, G. (1995). Gender and computing: Persisting differences. Educational Research, 37(3), 219-227.

EDUCAUSE Core Data Service Summary Report (2003). Available online at http://www.educause.edu/apps/coredata/reports/2003/

Egnatoff, W. (2002). Computers and Lifelong Learning. On-line Survey was available on January 15th, 2002 at http://educ.queensu.ca/ cll//

Herman, R. E. (2000, November 1). Liberal arts the key to the future. USA Today, 129 (26), 34-41.

Krahn, H., \& Bowlby, J. W. (2000). Education-job skills match: An analysis of the 1990 and 1995 national graduate surveys. Hull, Quebec: Applied Research Branch, Human Resources Development Canada. 
Lister, M., Dovey, J., Giddings, S., Grant, I., \& Kelly, K. (2003). New media: A critical introduction. New York, NY: Routledge.

Lyman, P. (1996). Technology and computer literacy. In N. H. Farnham \& A. Yarmolinksy (Eds.), Rethinking liberal education (pp. 109-123). New York, NY: Oxford University Press.

Lyman, P. (2001). Information literacy. Liberal Education, 87(1), 28-37.

Margolis, J. \& Fisher, A. (2002). Unlocking the clubhouse: Women in computing. Cambridge, MA: MIT Press.

McEuen, S. F. (2001). How fluent with information technology are our students? EDUCAUSE Quarterly, 4, 8-17.

Shapiro, J. J., \& Hughes, S. K. (1996). Information literacy as a liberal art: Enlightenment proposals for a new curriculum. EDUCOM Review, 31 (2). Available online at http://www.educause.edu/pub/er/review/reviewArticles/31231.html

Shashaani, L. (1995). Gender-based differences in attitudes towards computers. Computers and Education, 20, 169-181.

Statistics Canada. (1999). University enrolment full-time and part-time. Government of Canada. Available online at http://www.statcan.ca/english/Pgdb/educ03a.htm

Statistics Canada (2004). Community college postsecondary enrolment, by provinces and territories. Available online at http://www.statcan.ca/english/Pgdb/educ02a.htm

Sussman, D. \& Yssaad. L. (2005). The rising profile of women academics. Perspectives on Labour and Income, 6 (2). Available online at http://www.statcan.ca/Daily/English/050224/d050224c.htm

University of British Columbia. (2002). Faculty of Arts Home Page. Available online at http://www.arts.ubc.ca/FOA/foa.cfm?page=Units\&v1=Departments\&v2=Schools

University of New Brunswick. (2002). Faculty of Arts Home Page. Available online at http://www.unbf.ca/arts/

Women in Technology North West. (2004). The Social Culture of IT. Available online at http://www.isi.salford.ac.uk/gris/winwit/Gender.html

World Bank. (2005). Gender and Development. Available online at http://web.worldbank.org/

\section{Biographies}

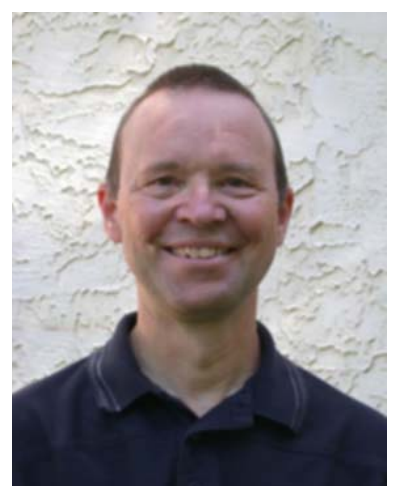

Terry Butler is the Director, Research Computing at the Arts Resource Centre at the University of Alberta. The Centre is a focus for IT initiatives in the Arts, for both instructional and research purposes. Terry is Executive Manager of the TAPoR node at Alberta: TAPoR is a humanities computing infrastructure which promotes and supports computing projects using text technologies and other digital approaches to the research in the liberal arts (http://tapor.ualberta.ca). 


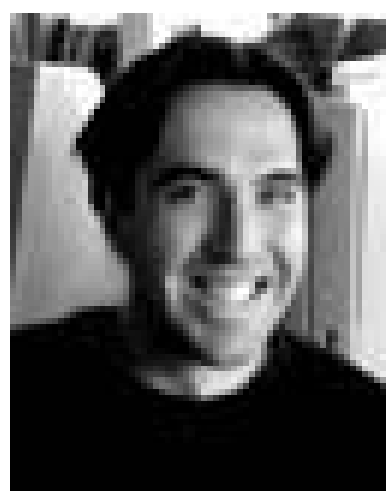

Peter Ryan is a Research Assistant, and formerly the Project Coordinator, for the Tech Edge Project Team. He is a doctoral candidate, and a Rogers Fellow, in the York/Ryerson Universities Joint Program in Communication and Culture (Toronto, Ontario). He completed his Master of Arts in Humanities Computing, specializing in English at the University of Alberta. His research interests include investigating how art affects the creation of technology, understanding how IT standardization bodies function, and exploring how IT can be used to better facilitate teaching.

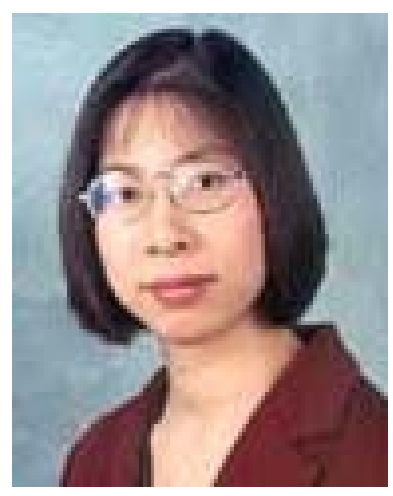

Tracy Chao (MA in Educational Technology, Concordia University) was an instructional designer at the University of Alberta at the time of the project. She now works for Royal Roads University, a distance education institution that offers full online professional programs. She collaborates with instructors to design, develop and implement elearning solutions, and she conducts action research in the use of technology in teaching and learning. 